の仮説は萧却されない，b）上り平均の差は有意となり， 患者の方が血清総蛋白量は低い結果をえた。

さて，われわれが大ざっばに心得ていると思っている 正常值を推計学的な取り扱いをし，さらに科学性をもた せて，も5一度，細汃く再検討空試みるために，血清総 蛋白量について，一見, 正常值とおもわれるデータを正 常対照者群をとり比較検討を試みた。

\section{結 論}

突難患者の血清総蛋白量について，正常対 照值をと り，統計分析を試みた。

血清総蛋白量について，二つの標本集団は $\mathrm{F}$ 一㭘定の 結果ではともに正規等分散であった．またT一検定では $5 \%$ 危険率で有意差が認められ，突難患者群の方が正 常対照者群より低いと結論した。

質問 大和田健次郎（東京学大）１）症例は㔖難の ランダムサンプルと考えてよいか，2）突難にも種々の 原因があるだろう，層別抽出の必要があるのではない か．3）対症は健康人を対照とすべきでないか。応
答 大崎勝一郎 (岡山日赤). 1） サンプルは全数統計 である，2）演者らは梁発性難㯖と球結膜のスラッジ現 象とは関倸が深いという結果をえているので血清総蛋白 量をチェックした，3）コントロール群に全く健康人を 採血出来ればよいが，実際上，困難なので，やむをえず このよらなコントロール群の取り方となった，質問 柳田則之（名大），蛋白分系は日差変動がみられるが， いつ検查されたか，対照例との差がみられたがこれれ が，原因の一つに考えている sludge にどれ位影響が あると考えるか. 応答 大崎勝一郎 (岡山日赤). 1）突難群，コントロール群とも，朝食後 3 時間以上释 過したものから採血した．2）スラッジ現象との関保で Dysprotemia の有無をこの際，チェックした。 追加 柳田則之（名大）．私共の蛋白分量検查成績（発病後 14 日以内のもの 102 例) では殆んど正常値にするが正常值 の中でもばらつきがみられ，r-globulin が上昇している むのがやや多、

B $79-1150-23522$

\title{
92. 蝸電図よりみた突発性難聴の病態
}

\section{○土肥勝徳・西田裕明・沢田正道・椳上秀伯（長崎大）}

昭和50年度に長崎大学耳壆咽喉科を受診した突発性難 聴34例を対象とし，蝸電図検查をおこないその反応波 形から突発性㩲㯖の予後判定および病態について榆討し t.

\section{反応波形の分類}

1. AP high response：L-part が久損し，H-part に おいて大きな電位がえられ，かつ入出力曲線において振 幅が急峻なカーブを示す。

2. Dominant-SP : L-part が久損し，H-part におい て CM 開始時にほぽ一致して，APの潜時よりはるかに 短汃く，基線より負極側に偏位し，AP 出力電位と略々 同程度の電位が記録される。

3. decreased AP high response : L part が久損し, H-part における電位が低く，刺激強度の上昇にともな ら振幅の伸びが今ない，すなわち入出力曲線が緩慢な力 ーブを示す
4. AP low response : 90-100dB HL の最大刺激に おいて L-partににみられるような 潜時が長い遅延反応を 示し，かつ出力電位が著しく低い反応しか得られない。

5. + SP or - SP : AP 反応が得られず，音刺激開始 時に一致して基線より正または負側に偏位した電位しか 記録されない．

6. $\mathrm{AP}, \mathrm{SP}$ no response : 90-100dB HL の最大刺激 強度において AP, SP ともに全く記録されない

Type 1 は34例中 7 例，Type 2 は 8 例にみとめられ， いふれも予後良好であった，その他の Type はいうれれ 予後不良であった。

\section{蝸電図よりみた突発性難聴の障害部位}

\section{1. 感賞細胞, 聴神経の一時的機能障害}

Dominant-SP $\ngtr \mathrm{AP}$ high response を示才例は $\mathrm{CM}$ も良好な反応を示し，全例に浩療または著明回復が得ら れ，かつメニエール病の蝸電図とも極めて類似してお 
り，突発性難聴の中でこのよ5な反応を示す例では少な くとも有毛細胞や聴神経には器質的障害が生じていると は考えにくく，有毛細胞および presynaptic region で の活動性は保たれているにもかかわらず，何らかの原因 で neural level または内リンパ腔内の可逆性の物理 的, 化学的障害により感喾緗胞, 㹔神経が一時的機能的 ブロックの状態にあるのではないかと思われた。

2. $\mathrm{AP}\left(\mathrm{N}_{1}\right)$ レベルの障害

純音㙏力検查で高度難聴を示し，蝸電図でもAP は 全く反応がえられないにもかかからず $\mathrm{CM}$ 恃間值，電 位とも正常值を示すことがある。このような例は流行性 耳下腺炎後の蝸電図でも度々みとめられる。このような 例では有毛細胞には障害があるとは洘え難く，㯖神経の $\mathrm{AP}\left(\mathrm{N}_{1}\right)$ レベルの障害と考えられる.

3. 感喾細胞または㯖神経の器質的障害

螎電図で decreased AP high response, AP low response, AP, SP no response Type で CM の反応も昰い 例では，その障害程路が neural level を介してか，内 リンパ腔内の物理的，化学的変化を介してか，あるいは 両者の混合したものか，いゔれにしても有毛細胞または 聴神経を含めた高度の器質的障害が推測される。

質問 棚橋汀路 (名大分院). 高度䧼聴で CM, AP 共 に良好例の病変部位, SP 記録の time scale, 純音聴検
と螖電図検查の日時の差は, 検查完了 Echo の有無, AP の波形異常の有無とその解釈について。応答 土肥 勝德 (長崎大). $\mathrm{N}_{1}$ レベルよりも後方で障害されてい ると考えることもできるが，われわれは音刺激に対して は電気的反応を示すが，他に機能的ブロックによる一過 性の障害と考えている. 殆んどの例で，同じ日に検查を 行なっているが，都合により1〜2 日後に行なった例む ある，SP 自身の振幅ではなく，AP 振幅との比較にお いて，優位か否かについて考えている。 Time Scale 注 常に一定にしている。+SP と一 $\mathrm{SP}$ とが同時に測定さ れる現象については，両者の変生部位が異なっており， 一方が俊位に出たり，両方が同時に測定されることもあ るのではないかと推定している。応答 西田裕明(長 㥓大). 症例 1 亿対する反応に $\mathrm{P}_{1}$ 成分を考慮する必要 があると考えている，な扔私達の検查室では Echo 成分 が同時に記録される。質問 丹羽英人（名大），蝸 電図により推定される障害部位上突難の子後に何か関係 があるかど 5 か. 応答 土肥勝徳 (長崎大). AP high response 顿よび Dominant -SP Type はすべて 予後良好で，その他の Type はすべて不良であった。 $y=エ ー ル$ 病や Industrial Sudden Deafness \&非常に 類似したパターンを示すが全く巽なった経過をとる。

\section{B 79-1151-25501}

\section{3. 突 発性難 聴 の自然治 癒}

中村興治・山地誠一・寺山吉彦 (北大)

突発性難聪には自然治渏があることを認めている人は 多いが，奏際には何等かの治潦を行らので詳細な検查を 行った自然治瘾例の報告はほとんどない，昭和49年 1 月 〜 51年 3 月までの当科の突発性難德症例は91例で，その 5 与厚生省突発性難聴調查研究班判定基準により, 治㓡 は19例であった，さらにこの19例中，種々の事情で治療 を行えなかった自然治痖例は 6 例であった。これら自然 治㭸例の恥力検查成績と治痖過程を険討することは本症 の本態解明と予後の判定に寄与すると考えて報告する。

症例は男 3 例, 女 3 例で，年令は 23 才 53才，6例の 初診時平均㯖力損失はそれぞれ $39 \mathrm{~dB} 84 \mathrm{~dB} 78 \mathrm{~dB} 78 \mathrm{~dB}$
$49 \mathrm{~dB} 54 \mathrm{~dB}$ で 2 例に反対耳にも感音難聴がみられた．

初診時聴力型心，低音障害型 3 例，水平型 1 例，山型 1 例, S 型 1 例と 6 例中 4 例は低音障害型, 水平型を呈 したことは，これらの型は予後が良好であることを示し ている、レクルートメント現象は全例に陽性であった。 前庭症状は全例に認められなかった。

つぎに発症より初診までの期間と予後については，従 来より発症後早期に治療を受けたものほど予後がよいと されている。一方われわれの自然治䔳例は 6 例中 5 例が 発症後 3 日以内に受診していることよりみれば，従来の 郝告中の早期治療を受けて治療したものの中には自然治 